\title{
Single-zircon $\mathrm{Pb}$-evaporation and ${ }^{40} \mathrm{Ar} /{ }^{39} \mathrm{Ar}$ dating of the metamorphic and granitic rocks in north-west Spitsbergen
}

\author{
Yoshihide Ohta, Alexander N. Larionov, \\ Alexander M. Tebenkov, Claude Lepvrier, \\ Henri Maluski, Michael Lange \& Barbara Hellebrandt
}

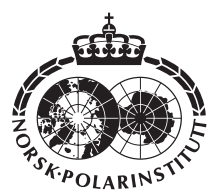

\begin{abstract}
North-west Spitsbergen consists of a complex of Caledonian and Grenvillian crystalline rocks, situated at the north-west corner of the Barents Shelf. The aim of this study is to understand the extent of pre-Caledonian basement rocks and their protoliths. Micas and zircon grains from six rocks from north-west Spitsbergen have been dated by the ${ }^{40} \mathrm{Ar} /{ }^{39} \mathrm{Ar}$ and single-zircon $\mathrm{Pb}$-evaporation methods. Two grey granites yielded Late Caledonian mica ${ }^{40} \mathrm{Ar} /{ }^{39} \mathrm{Ar}$ and zircon ages of ca. 420-430 My, with inherited zircon grains as old as $1725 \mathrm{My}$. Zircon grains from a gneissose granite xenolith in a grey granites gave crystallization ages of ca. $960 \mathrm{My}$; some grains from a migmatite neosome show similar ages. Zircon grains yielding Archean and late Palaeoproterozoic ages (1600-1800 My) are interpreted as xenocrysts of detrital origin. The youngest ages obtained from detrital zircon grains from a greenschist facies quartzite of the Signehamna unit are ca. 1800 My. Similar schists are included as xenoliths in the 960 My old gneissose granite; therefore, the sedimentary protoliths of the unit are Mesoproterozoic. The dating results suggest a significant tectonothermal event during Grenvillian time; subsequent Caledonian events had less extensive thermal effects. However, it is still a matter of debate whether Grenvillian or Caledonian metamorphism produced the majority of the migmatites. A large population of zircon grains with Late Palaeoproterozoic ages suggests a wide surface exposure of rocks of this age in the source area, with some Archean zircons.
\end{abstract}

Y. Ohta, Norwegian Polar Insitute, c/o NGU, Box 5348, Majorstua, N-0304 Oslo, Norway; A. N. Larionov, Laboratory for Isotope Geology, Swedish Museum of Natural History, Box 50 007, SE-104 05 Stockholm, Sweden; A. M. Tebenkov, Polar Marine Geological Expedition, ul. Pobedy 24, 189510 Lomonosov-St. Petersburg, Russia; C. Lepvrier, Dept. of Geotectonics, P. \& M. Curie University, 4 Place Jussieu, F-75252 Paris Cedex 05, France; H. Maluski, Laboratory of Tectonics and Geochronology, University of Montpellier, Place E. Bathillon, 34000 Montpellier, France; M. Lange \& B. Hellebrandt, German Aerospace Centre, Koenigswinterer Str. 522-524, D-53227 Bonn, Germany.

Svalbard is located at the north-western edge of the Baltic plate. In the late Meso- and early Neoproterozoic, this archipelago lay near the triple junction of Laurentia, Baltica and Siberian plates in the Rodinia supercontinent (e.g. Dalziel 1997; Torsvik \& Rehnström 2001). Pre-Devonian basement rocks are exposed along the western and northern coasts of the archipelago. The north-western basement area treated here is dominated by various gneisses, migmatites and metamorphosed supracrustal rocks (Fig. 1).

Several geologists worked in the area during the 1960s and 1970s (e.g. Gayer et al. 1966; Gee \& Hjelle 1966; Ohta 1969; Hjelle \& Ohta 
1974; Hjelle \& Lauritzen 1982). Hjelle (1979) and Ravich (1979) summarized the findings and concluded that the meta-supracrustals were deposited during Riphean time and metamorphosed in the Caledonian orogeny. This idea had been first proposed by Holtedahl $(1914,1926)$. The existence of pre-Caledonian basement was proposed by Krasil'ščikov (1979) and Abakumov (1979), and some Grenvillian zircon ages were obtained by Barašov et al. (1996a). (The term "Grenvillian" is used in a broad sense, meaning the late Mesoproterozoic orogenic events in the Rodinia supercontinent.) This paper presents a summary of the ${ }^{40} \mathrm{Ar} /{ }^{39} \mathrm{Ar}$ and single-zircon $\mathrm{Pb}$-evaporation analyses applied to the metasupracrustals, migmatites, and granitic rocks of this area to get the extent of the pre-Caledonian basement. This is important to correlate geological units of palinspastically neighbouring plates. (Data tables are available from A. N. Larionov. See also Ohta et al. in press).

\section{Geological setting}

The southern boundary of the crystalline basement of north-west Spitsbergen is submerged under Kongsfjorden. The eastern border is a north-south trending fault, the Raudfjorden Fault (RF in Fig. 1). The grade of metamorphism and degree of migmatization increase from south to north, partly as a consequence of the gentle southward plunge of structural axes (e.g. Gee \& Hjelle 1966).

The meta-supracrustal rocks have been divided into three tectono-stratigraphic formations (Gee \& Hjelle 1966). In descending order, these are: the Generalfjella Formation, consisting mainly of marbles; the Signehamna Formation, of psammopelitic phyllite-schists with quartzites; and the Nissenfjella Formation, of micaceous gneisses with subordinate amounts of amphibolites and marble-skarns (included in migmatites in Fig. 1). This division is generally valid in terms of lithological characteristics, but the boundary relationships among them are mostly tectonic, especially in the middle part of the area. Therefore, these formations are hereafter be called "units".

A granitic rock, called "grey granite" in previous literature, cuts all three units as subconcordant bodies and is thought to be a Caledonian intrusive. A large granite batholith, the Hornemantoppen granite, was intruded subse- quent to the grey granite in the middle of the area.

Apparent gradational transitions of metamorphic grade are seen within four inferred north-south trending structural zones, described below, which are bound by faults and shear zones. These boundaries are characterized by discontinuous coarse-grained, blastoporphyritic gneisses in the north, by faults in the south-west and east, and are associated with discontinuous intrusions of the grey granite in the south. Abrupt changes from schists to migmatites and structural discontinuities are seen across the zone boundaries (Fig. 1).

\section{Western structural zone (WSZ)}

The WSZ is composed, in the south, of the Generalfjella marbles and Signehamna phylliteschists on Mitrahalvøya. The middle part consists of garnet-biotite schists and the northern part is underlain by garnet-mica gneisses of the Nissenfjella unit. The metamorphic grade increases gradationally to upper amphibolite facies to form migmatites in the north.

The eastern boundary of this zone is a fault passing through the middle of Mitrahalvøya, extending to the north via eastern Nissenfjella to the western coast of Hoelhalvøya (Fig. 1). The Generalfjella marbles have a flat-lying thrust duplexes in the eastern half of the peninsula (MWSZ), while they have upright, tight folds in the west (WSZ). Blastoporphyritic gneisses and some grey granite bodies follow along the boundary in the north of Førstbreen. The boundary may represent a west-side down-throw or dextral displacement by the fault.

\section{Middle-western structural zone (MWSZ)}

This is a ca. $20 \mathrm{~km}$ wide zone. Its eastern boundary is defined by a zone of discontinuous grey granite bodies in the south, making lithological contrast to the migmatites in the east and schists in the west. An injection gneiss zone with blastoporphyritic gneisses in the middle, and a grey granite occur along the boundary from Lilliehöökbreen to the north-west coast of

Fig. 1 (right). Geological sketch map of north-west Spitsbergen, showing the sample localities. Map of Svalbard in upper right corner shows location of area featured in main sketch map. 


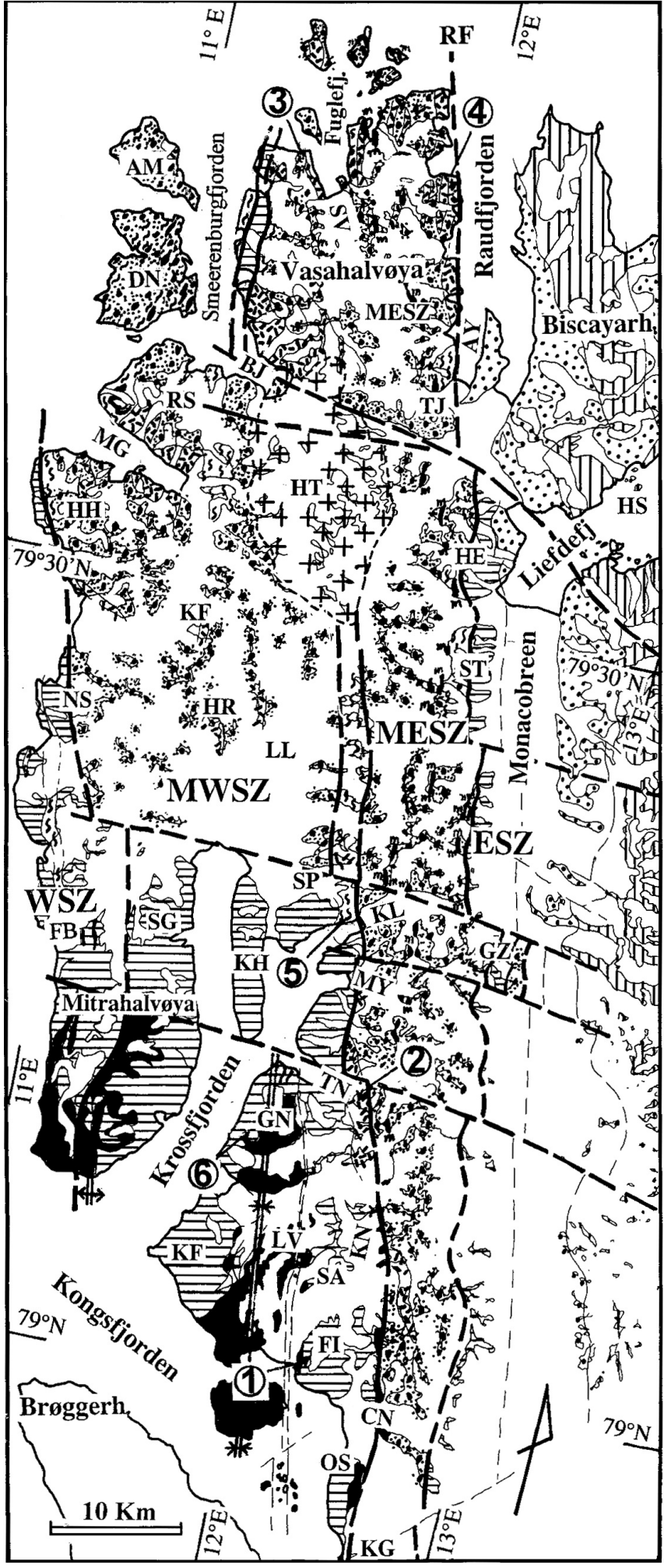

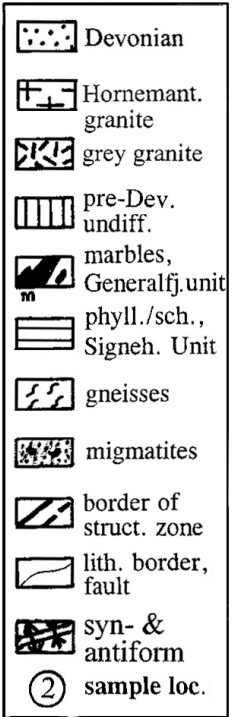

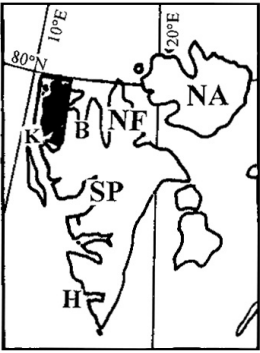

Key to abbreviations, map above

\section{SP: Spitsbergen} B: Bockfjorden $\mathrm{H}$ : Hornsund $\mathrm{K}$ : Kongsfjorden NA: Nordaustlandet NF: Ny Friesland

Key to abbreviations, map at left

WSZ: western structural zone

MWSZ; middle-western structural zone MESZ: middle-eastern structural zone ESZ: eastern structural zone

RF: Raudfjorden Fault

AM: Amsterdamøya

AY: Ayerfjorden

BJ: Bjørnfjorden

$\mathrm{CN}$ : Conwaybreen

DN: Danskøya

FB: Førstebreen

FI: Feiringfjellet

GN: Generalfjella

GZ: Gazertfjellet

HE: Hesteskoen

HH: Hoelhalvøya

HR: Huriefjellet

HS: Hesteskoholmen

HT: Hornemantoppen

KA: Kaffitoppen

KF: Krossfjordflya

KG: Kongsbreen

KH: Kong Haakons Halvøy

KL: Kollerbreen

KN: Konsulbreen

LL: Lilliehöökbreen

LV: Løvlandfjellet

MG: Magdalenefjorden

MY: Mayerbreen

NS: Nissenfjella

OS: Ossian Sarsfjella

RS: Reuschhalvøya

SA: Svansen

SG: Signehamna

SP: Supanbreen

ST: Stortingspresidenten

SV: Svitjodbreen

TJ: Tjukktarmen

TN: Tinayrebreen. 
Bjørnfjorden. The northernmost extension of the boundary zone is a schistose rock unit intruded by numerous thin aplitic layers, along the eastern coast of Smeerenburgfjorden.

The southern part of the MWSZ consists mainly of the Generalfjella marbles and structurally underlying Signehamna semipelitic and psammitic phyllite-schists. The metamorphic grade increases to the north and east from greenschist to amphibolite facies. The boundary may show a dextral or west-side down-throw faulting.

On eastern Mitrahalvøya, the Generalfjella marbles lie nearly horizontally as thrust sheets on the Signehamna schists, forming a half-antiform (the western half is missing) (Peletz et al. 1997; Piepjohn et al. 1997), while on the eastern side of Krossfjorden they form a north-south trending open synform. The Generalfjella and Signehamna units are separated by reverse faults moderately dipping towards the synform axis on both eastern and western limbs of the synform.

The Hornemantoppen batholith is located roughly in the middle of this zone and is younger than the grey granite, since the former contains xenoliths of the latter, though the single-zircon $\mathrm{Pb}$-evaparation ages of these two granitic rocks overlap (Balašov et al. 1996a). Grey granite bodies are subconcordantly intruded into the migmatites on the west side of Lilliehöökbreen, on both sides of Magdalenefjorden, on Danskøya and on Amsterdamøya. In the south of Kollerbreen, grey granites along the eastern boundary intrude into the Signehamna schists and migmatites and contain xenoliths of the schists, though the contacts are often sheared later.

Various migmatites are developed widely in the northern part of this zone. Granitic neosomes occupy more than $30 \%$ of the volume of the migmatites. The gneissic restites are commonly rotated in the neosomes. Some gneiss-dominant areas are recognized in western Reuschhalvøya, middle Danskøya and western Amsterdamøya (Fig. 1). Relict kyanite grains in some gneisses suggest metamorphism at intermediate pressures during the prograde path. Sillimanite-cordierite assemblages are common in most of the metapelitic restites. Amphibolites and marbles also occur as restites. Granulite facies conditions were reached during the peak of metamorphism in the northern part of this zone (Hjelle \& Ohta 1974; Abakumov 1979; Klaper 1986; Sirotkin 1996). Three or more deformation phases have been recognized in the mesoscopic structures, including at least two stages of schistosity development before the migmatitization (Gee \& Hjelle 1966; Hjelle \& Ohta 1974; Hjelle 1979; Lange \& Hellebrandt 1999).

\section{Middle-eastern structural zone (MESZ)}

The eastern boundary of this structural zone is a sharp, steeply east-dipping fault - the Raudfjorden Fault-along the western sides of Raudfjorden in the north, where it separates migmatites from Devonian rocks, and a fault ca. $5 \mathrm{~km}$ west of Monacobreen in the middle and south, making a distinct change from migmatites in the west to psammitic schists to the east, which suggests a east-side down-throw fault.

Migmatites of various types occur throughout this zone, and some grey granite bodies occur north of Conwaybreen and in Vasahalvøya. Coarse-grained, feldspathic porphyroblastic gneisses, and lesser amounts of quartzite, marbleskarn and amphibolite constitute the restites and have upper amphibolite facies mineral assemblages. Granitic neosomes locally represent almost half the volume of the migmatites. The restites of migmatites show granulite facies metamorphism, indicated by calc-silicate mineral assemblages from north-western Vasahalvøya (Bucher-Nurminen 1981) and Al-rich mineral assemblages in pelitic gneisses from the eastern side of Smeerenburgfjorden (Hjelle \& Ohta 1974; Klaper 1986).

Two or more alignments of small, discontinuous marble-skarn bodies occur in the middle of this zone. The marble-skarns may be interpreted as remains of the Generalfjella marbles, since they align on the northward extensions of the latter (Gee \& Hjelle 1966; Hjelle \& Ohta 1974; Ravich 1979). Krasil'ščikov (1979) and Abakumov (1979) considered the restites in the migmatites to have been derived from older basement rocks including the Nissenfjella unit.

\section{Eastern structural zone (ESZ)}

A zone of micaceous schists occurs in the eastern part of the study area along the west side of Monacobreen (Fig. 1). Migmatites occur to the east of the schists at Gazertfjellet, though their extent is unknown due to ice cover. The rocks are medium-grained, strongly schistose semipelitic and psammitic rocks, and have a monoclinal structure dipping moderately to the east.

Single-zircon $\mathrm{Pb}$-evaporation and ${ }^{40} \mathrm{Ar} /{ }^{39} \mathrm{Ar}$ dating 
Quartzitic schists are dominant to the northeast of this zone.

\section{Previous isotopic dating}

Most $\mathrm{K}-\mathrm{Ar}$ and $\mathrm{Rb}-\mathrm{Sr}$ whole rock and mineral isochron ages obtained before 1980 (Gayer et al. 1966; Hjelle 1979; Krasil'ščikov 1979; Ravich 1979) recorded a middle Silurian-Devonian, Late Caledonian thermal event ca. 380 - 430 Mya.

In Svalbard, Early and Late Caledonian events are distinguished by an angular unconformity at the base of upper Ordovician, observed in Motalafjella, central western Spitsbergen (Ohta et al. 1989). There underlying subduction duplexes of blueschists and eclogites, with the age of $>470 \mathrm{My}$ (hornblende ${ }^{40} \mathrm{Ar} /{ }^{39} \mathrm{Ar}$ age; Dallmeyer et al. 1990a), are covered by an upper Ordovicianmiddle Silurian fossiliferous succession (Ohta et al. 1984). The Late Caledonian event is defined to be in the age range younger than ca. $430 \mathrm{My}$ to Early Devonian, and deforms the fossiliferous succession.

Single- and multi-zircon grain ${ }^{207} \mathrm{~Pb} /{ }^{206} \mathrm{~Pb}$ evaporation dating (Balašov et al. 1996a) on the grey granite from Bjørnfjorden yielded Caledonian ages of 421-461 My, as well as three older ages of 547, 561 and $952 \mathrm{My}$. Analyses of the Hornemantoppen granite yielded a $\mathrm{Rb}-\mathrm{Sr}$ whole rock age of $412 \pm 5 \mathrm{My}$, consistent with Hjelle's (1979) result of $414 \pm 10$ My obtained by the same method.

Multi-grain single-step $\mathrm{Pb}$-evaporation analyses of zircon grains, carried out at the Isotope Geochronology Laboratory in Apatity, Russia (Tebenkov, unpubl. data), gave two ages of 1136 and 1050 My from the grey granite on Bjørnfjorden's north-west coast. Populations of detrital zircon grains from the micaceous schists of the Signehamna unit, east of Krossfjorden, yielded mixed ages of ca. 1645 My and 1650 My. This suggests the existence of Precambrian zircon growth events, but their extent has not been known.

\section{Analytical methods}

\section{${ }^{40} \mathrm{Ar}{ }^{39} \mathrm{Ar}$ method}

Purified samples of muscovite and biotite were irradiated at the Centre d'Etudes Nucleaires de
Grenoble, France, for 24 h, with a standard hornblende Caplongue (344.5 $\pm 1.2 \mathrm{My})$. The analyses were performed following standard laboratory techniques (Maluski et al. 1995) at the laboratory of University of Montpellier. The age was calculated from the largest incremental segments.

\section{Single-zircon Pb-evaporation analysis}

The technique proposed by Kober $(1986,1987)$ and described by other authors (e.g. Hellman et al. 1997 and references therein) has been applied. The isotopic analyses were performed at the Laboratory for Isotope Geology at the Swedish Museum of Natural History, using a Finnigan MAT 261 mass spectrometer; the ages were calculated following the methods and procedures of Ludwig (1991) and Stacey \& Kramers (1975). The common $\mathrm{Pb}$ correction and calculation of the ${ }^{207} \mathrm{~Pb} /{ }^{206} \mathrm{~Pb}$ age for each scan were performed using the software developed by Torsten Persson, at the Laboratory for Isotope Geology, Swedish Museum of Natural History, with errors in $2 \sigma$. In cases where apparent age increases until the end of the analysis, the result from the last evaporation step defines a so-called "minimum age", which should not be regarded as corresponding to any real geological event. A plateau age is calculated from the three or more last step ages, which overlap in their error ranges.

\section{Samples and dating results}

Analysed samples were collected from six localities, as shown in Fig. 1. (Tables of isotopic analysis data are available in Ohta et al. in press.)

Sample 1: Mica schist from Feiringfjellet, northwest Conwaybreen.-Mica schists, locally containing chloritoid, staurolite and garnet, occur immediately below the base of thick Generalfjella marbles on the south-western foothill of Feiringfjellet (Fig. 1) (Lange \& Hellebrandt 1999).

The analysed schist has a strongly wavy schistosity. The matrix has a fine-grained, lepidoblastic texture with small flakes of brown biotite and contains a large amount of polygonal quartz, minor dusty feldspar and poikiloblastic garnet, which shows cataclastic textures near the schistosity planes, and this matrix is superposed by the coarse-grained micas. The strong schistosity is defined by dense, parallel 

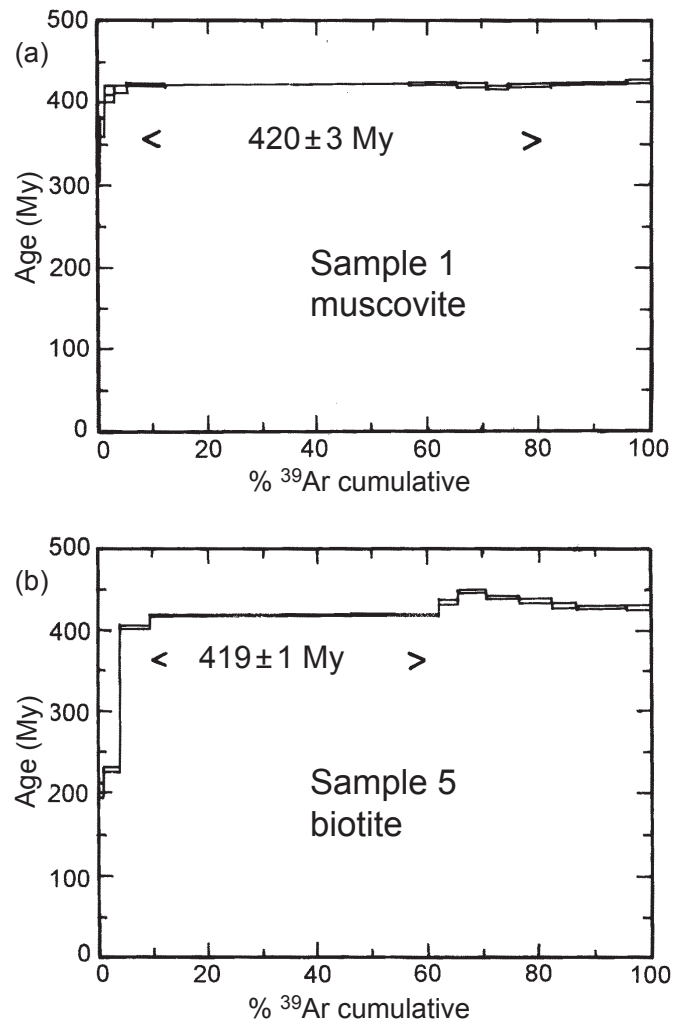

Fig. $2 .{ }^{40} \mathrm{Ar} /{ }^{39} \mathrm{Ar}$ isotopic age diagrams. (a) Incremental age spectra of muscovite from sample 1, Feiringfjellet. (b) Incremental age spectra of biotite from sample 5, Kollerbreen.

aggregates of large brown biotite and muscovite flakes, both folded into millimetre-scale chevron folds. Fibrous bandles of sillimanite overgrew on the coarse biotite flakes. The coarse-grained micaceous schistosity appears to have been formed as a result of thrust movements along the boundary between the marbles and underlying Signehamna schists. Ravich (1979) postulated a pulse of thermal metamorphism caused by the emplacement of Caledonian granitic rocks around this locality and the growth of sillimanite reflect that event.

Muscovite was separated from this strongly foliated schist and analysed by the ${ }^{40} \mathrm{Ar} /{ }^{39} \mathrm{Ar}$ method. An age of $420 \pm 3$ My was obtained from the release spectrum (Fig. 2a) and a slightly younger age of $415 \pm 4 \mathrm{My}$ was obtained from the inverse ${ }^{36} \mathrm{Ar} /{ }^{40} \mathrm{Ar}$ vs ${ }^{39} \mathrm{Ar} /{ }^{40} \mathrm{Ar}$ isochron.

These ages are within the age range of a Late Caledonian thermal event (380 - 430 My K-Ar ages of Ravich 1979; Ohta et al. 1989) and are similar to the magmatic age of the undeformed grey granite from Tinayrebreen (sample 2), described below, on the boundary between the MWSZ and MESZ. The obtained age therefore probably represents the thermal effect of the granitic intrusions (Ravich 1979), while movement on the reverse fault occurred more than once, before and after the thermal event.

Sample 2: Grey granite from Tinayrebreen, east of Krossfjorden.-A $3 \mathrm{~km}$ wide and $10 \mathrm{~km}$ long homogeneous grey granite body, one of the granite intrusions along the boundary between the MWSZ and MESZ, occurs at the western end of Tinayrebreen (Fig. 1). The granite was intruded into the neighbouring schists and gneisses of the Signehamna unit in the west as subconcordant sheets, while it has a sheared contact with the migmatites in the east.

The dated sample is a medium-grained granodiorite-monzogranite. Biotite is the only major mafic mineral. The texture is hypidiomorphic polygonal, a typical igneous texture without planar structure.

Most zircon grains show concentric, magmatic zoning (Fig. 3). Three zircon grains (A, B, and C) have well developed, smooth facets and growth zoning. The fourth grain (D) has a distinctly anhedral and rounded shape.

Two Caledonian $\mathrm{Pb}$-evaporation plateau ages$422 \pm 4.5 \mathrm{My}$ from grain C and $427 \pm 6.5 \mathrm{My}$ from grain A (average $424 \pm 4$ My) (Fig. 3)-indicate the time of crystallization of the granite. Grain B gave a slightly older age of $512 \pm 4$ My with a weak increase of age in the last three evaporation steps and this may be a minimum age. The rounded grain (D) yielded a minimum age of $1251 \mathrm{My}$, indicating the incorporation of old inherited grains from depth. A crustal origin of this Caledonian granite is therefore inferred.

Some elongated bodies of massive granites occurring along the MWSZ-MESZ boundary have a similar occurrence and lithology, and have xenoliths of schists and sheared margins to the migmatites in the east. Our dating results show that the granitic rocks of this boundary were emplaced during Late Caledonian time, though the boundary between the structural zones could coincide with an older tectonic suture or fault zone.

Sample 3: Grey granite from Fuglefjorden, north-western Vasahalvøya-A massive, homo- 
Fig. 3. Sample 2, grey granite from Tinayrebreen, eastern side of Krossfjorden: dated zircon grains and their age spectra. For Figs 3 - 7, ages preceded by $=$ are plateau ages; ages preceded by $>$ are minimum ages. Photographs in all figures illustrate various morphologies, but do not represent specific analysed grains. Transmitted light in glycerine, longest side ca. 1.5 $\mathrm{mm}$. Left: idiomorphic grain with a few inclusions. Middle: partly resorbed grain with large inclusion or core. Right: rounded, inherited grain.

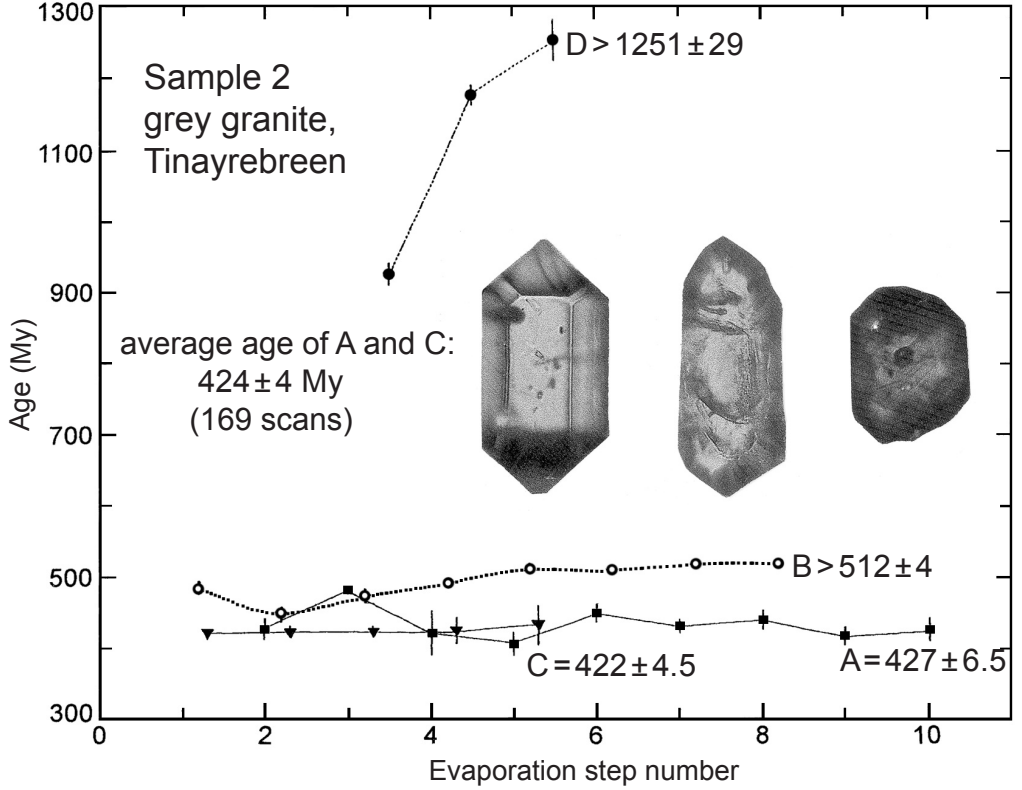

geneous grey granite body, ca. $500 \mathrm{~m}$ wide and $2 \mathrm{~km}$ long, occurs on the south-western coast of Fuglefjorden (Fig. 1). It has a sharp and roughly concordant intrusive contact with the surrounding migmatites, and contains angular xenoliths of migmatites and gneisses.

The dated sample is a medium-grained granitemonzogranite, containing small prismatic phenocrysts of oligoclase. The rock plots close to the eutectic valley of the Qz-Pl-Kf diagram (Hjelle \& Ohta 1974; Balašov et al. 1996a). The grey granites throughout Vasahalvøya are calcalkaline, high- $\mathrm{K}_{2} \mathrm{O}$, S-type granites and plot in the fields of continental arc granitoids and continental collision granitoids (Maniar \& Piccoli 1989).

Two morphological types of zircon were distinguished (Fig. 4). Type 1 includes subhedral and euhedral, short to long prismatic grains (A, B, $\mathrm{D}, \mathrm{G}, \mathrm{J})$ in which oscillatory zoning is often seen. These grains are dominant in the population. Type 2 grains (F, M) are anhedral, rounded to various degrees, and are xenocrysts. The presence of this second type suggests the existence of older cores within grains of type 1 .

Six zircon grains yielded Caledonian ages (Fig. 4), with five showing $\mathrm{Pb}$-evaporation plateau ages: $\mathrm{K}=419 \pm 4 \mathrm{My}, \mathrm{A}=425 \pm 6 \mathrm{My}, \mathrm{D}=425 \pm 4 \mathrm{My}$, $\mathrm{E}=425 \pm 25 \mathrm{My}$, and $\mathrm{J}=430 \pm 110 \mathrm{My}$, yielding an average age of $423 \pm 3$ My (Fig. 4b). These ages are interpreted as the age of granite crys- tallization. One grain $(\mathrm{F})$ gave a minumum age of $522 \pm 5$ My and another grain $(\mathrm{G})$ showed older ages at the beginning of the analysis by unknown reason. Grain L gave a minimum age of $450 \pm 220 \mathrm{My}$. Grain M shows a plateau age (last 3 steps) at $1118 \pm 6$ My. Grain B (Fig. 4a) yielded a Caledonian plateau age of $427 \pm 12 \mathrm{My}$ in the first four steps, while the last two steps gave a minimum age of $1725 \pm 8 \mathrm{My}$. These results indicate that the grey granite assimilated old rocks, which contained inherited zircon grains as old as ca. $1730 \mathrm{My}$.

The Caledonian ages compare well with that of a larger body of grey granite on the north-western coast of Bjørnfjorden, which yielded zircon age of $423 \mathrm{My}$ and includes an older grain with an age of 952 My (Balašov et al. 1996a).

Sample 4: Granitic neosome of migmatite, southern coast of Hamiltonbukta, north-east Vasahalvøya.-Various migmatites occupy nearly the whole of Vasahalvøya in the northern MESZ. The amount of associated grey granite is greater in northern Vasahalvøya than in the south. Locally, these granites show intrusion breccia structure along their margins, with angular enclaves of migmatites.

Agmatitic structures are common in the migmatites. Assimilated gneisses and concentrations of biotite mark the foliations in the neosomes, and 
Sample 3 grey granite, Fuglefjorden

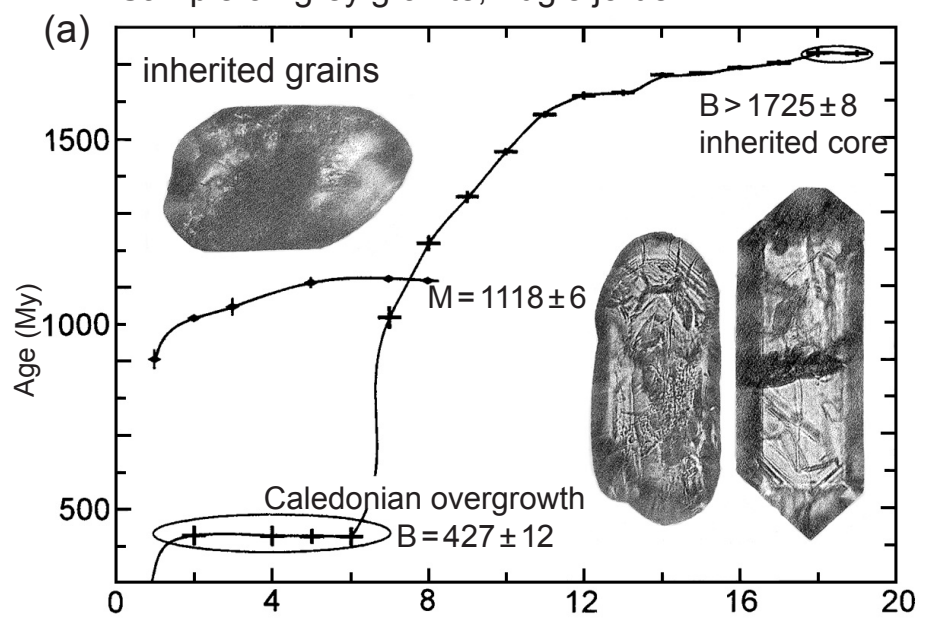

Fig. 4. Sample 3, grey granite from south-western coast of Fuglefjorden: zircon grains and their age spectra. See caption with Fig. 3. Left photograph: well rounded, inherited grain. Middle: rounded, zoned grain. Right: idiomorphic grain with thin prismatic inclusions; long side ca. $1.5 \mathrm{~mm}$.

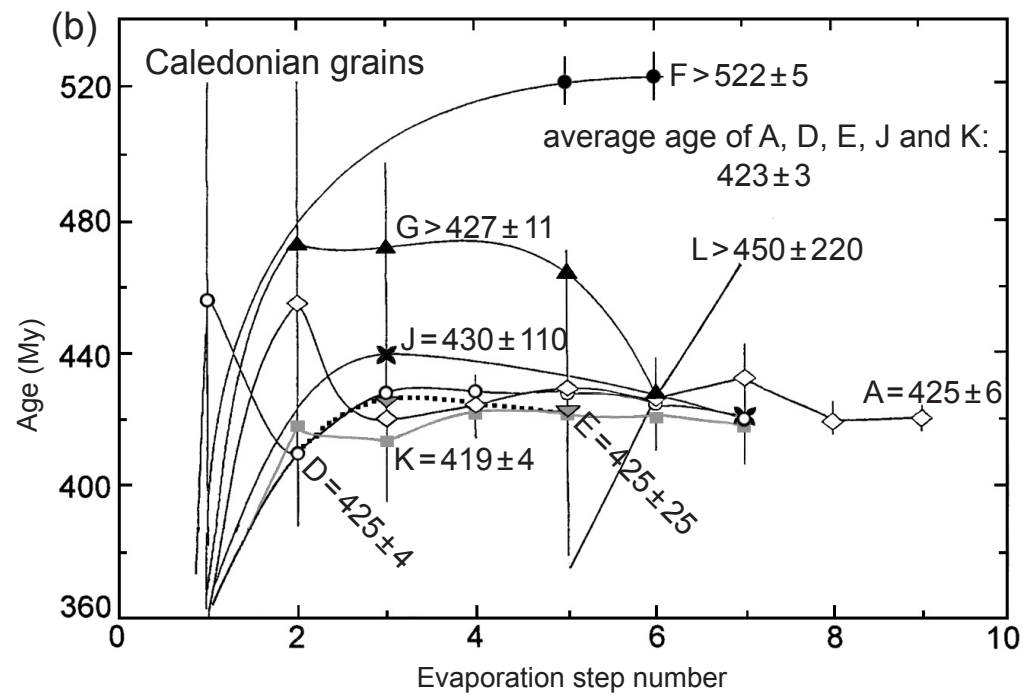

clots of cordierite are common. The boundaries between the neosomes and restites are relatively sharp, though gradational transitions are also observed. The neosomes may contain old zircon grains from digested paleosomes. The restites are micaceous gneisses with or without garnet, cordierite and sillimanite.

The dated sample (locality in Fig. 1) is a heterogeneous neosome of the migmatite, quartz diorite in composition. Quartz in the matrix shows an irregularly developed mylonitic texture with sutured grain boundaries, strongly wavy extinction and distinct elongated grain fabrics. This texture stands in sharp contrast to the undeformed texture in the grey granites.
Zircon grains from this rock include a mixture of subhedral and euhedral grains, as well as rounded ones (Fig. 5), and some have a magmatic oscillatory zoning. Observations of the cathodoluminescence (CL) images show that the subhedral and euhedral shapes were caused by U-

Fig. 5 (right). Sample 4, a migmatite neosome from southern side of Hamiltonbukta, north-western coast of Raudfjorden: zircon grains and their age spectra. See caption with Fig. 3. Upper left photograph: idiomorphic grain with small prismatic inclusions, ca. $1.5 \mathrm{~mm}$ long. Upper right: subidiomorphic grain with rough surface. Lower left: rounded grain. Lower right: CL images of zircon grains, showing discontinuous core. 


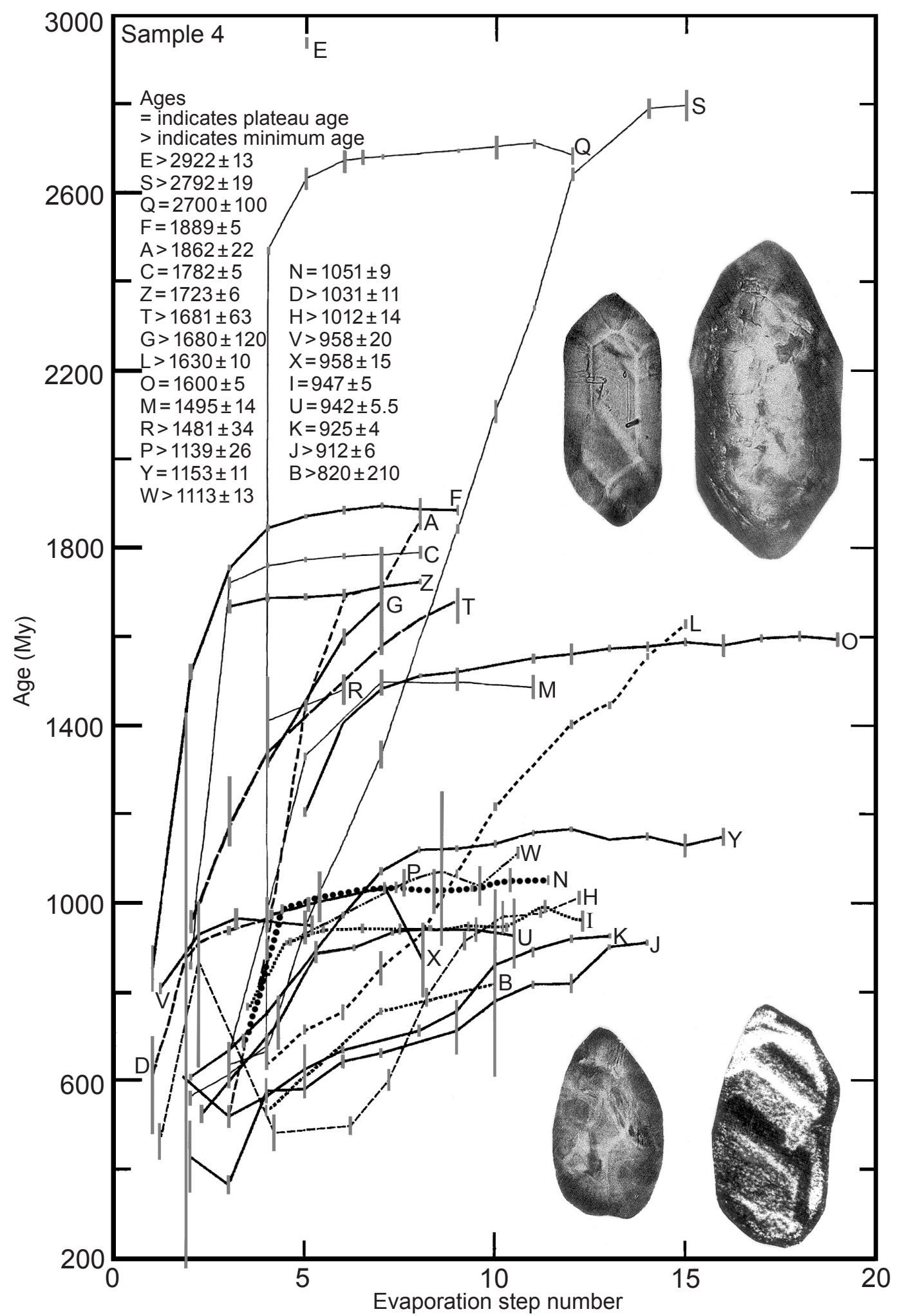




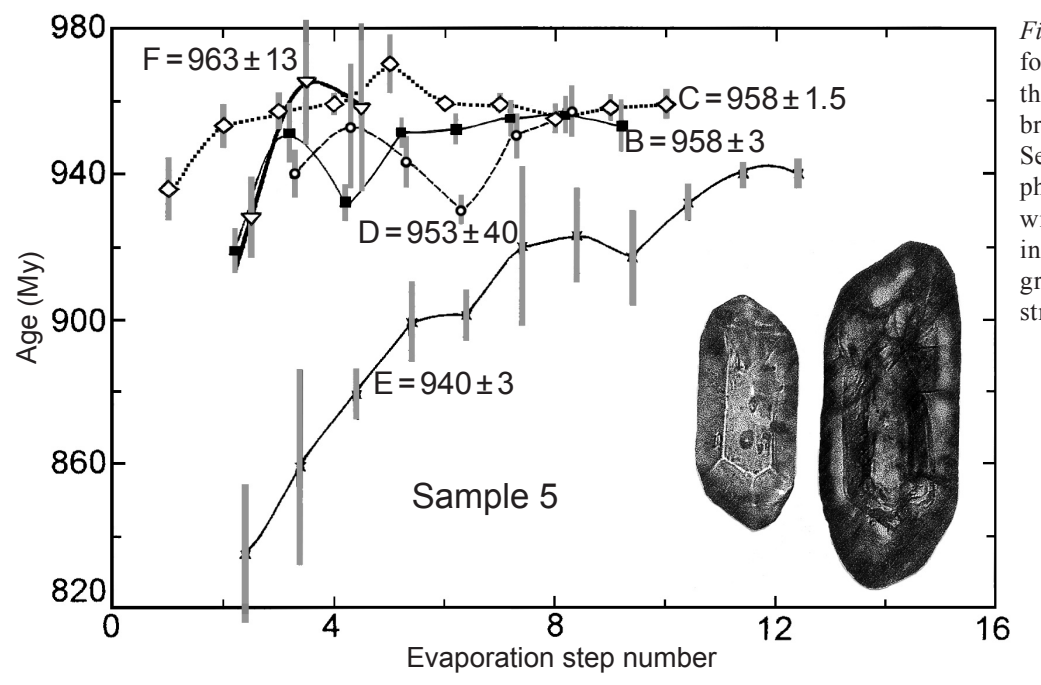

Fig. 6. Sample 5, age diagram for a gneissose granite from the north-western exit of Kollerbreen, north-east Krossfjorden. See caption with Fig. 3. Left photograph: idiomorphic grain with probable gas or liquid inclusions. Right: sub-rounded grain with complex inner structures, ca. $1.5 \mathrm{~mm}$ long.

rich overgrowth of zircon on round cores, which is typical for zircon grown in an environment of migmatization (Cornell et al. 1998). The rounded cores are sedimentary in origin, or could be formed by resorption before overgrowth (Brouand et al. 1990; Hartmann et al. 2000; Williams 2001).

Twenty-six zircon grains were analysed (Fig. 5). All grains show ages as young as ca. 430 My during early steps of evaporation, suggesting overgrowth during Caledonian time, but no grains yielded a Caledonian plateau age. This indicates that Caledonian conditions did not favour formation of new zircon. In addition to these indications of Caledonian zircon growth, four other plateau age groups are recognizable.

Age group 1. Ages range from ca. $910 \mathrm{My}$ to 1150 My (15 grains).- These can be divided into three subgroups:

$$
\begin{aligned}
& \text { 1a: } \mathrm{K}=925 \pm 4, \mathrm{X}=958 \pm 15, \mathrm{U}=942 \pm 5.5 \\
& \mathrm{I}=947 \pm 5, \text { and minimum ages of } \mathrm{B}>820 \pm 210 \\
& \text { and } \mathrm{J}>912 \pm 6 \\
& \text { 1b: } \mathrm{N}=1051 \pm 9 \\
& 1 \mathrm{c}: \mathrm{Y}=1153 \pm 11 \text { and five minimum ages of } \\
& \mathrm{V}>958 \pm 20, \mathrm{H}>1012 \pm 14, \mathrm{D}>1031 \pm 11, \\
& \mathrm{~W}>1113 \pm 13 \text {, and } \mathrm{P}>1139 \pm 26
\end{aligned}
$$

Most grains are euhedral or slightly rounded, except for a fragmental grain (K) and two clearly rounded grains (D and $\mathrm{W}$ ). Grains $\mathrm{X}, \mathrm{I}, \mathrm{J}$ and $\mathrm{V}$ are zoned, suggesting a magmatic growth. Grains K, I, U and V have a similar habit, but they gave different ages. Therefore, the grains of the subgroup la could be derived from different sources formed in the Grenvillian period. Most grains of subgroup la are zoned, and they yield the youngest ages of ca. 920-950 My. Accordingly, their ages probably represent the consolidation of the granitic neosome of the migmatite. Since no detailed CL observations were made prior to analyses, no conclusion can be drawn as to whether the 940-950 My old grains are rounded cores mantled by Caledonian overgrowth. The lack of grains with overall Caledonian ages indicates that Caledonian conditions did not favour formation of new zircon grains.

Age group 2. Ages range from ca. $1500 \mathrm{My}$ to ca. $1600 \mathrm{My}$ (6 grains).-One slightly rounded grain (M) yielded a plateau age of $1495 \pm 14 \mathrm{My}$. A euhedral grain $(\mathrm{O})$ yielded a plateau age of $1600 \pm 5$ My. Four prismatic grains yielded minimum ages of $\mathrm{G}>1680 \pm 120 \mathrm{My}, \mathrm{L}>1630 \pm 10$ My, $\mathrm{R}>1481 \pm 34$ and $\mathrm{T}>1681 \pm 63 \mathrm{My}$, and may be related to Age group 3. The two plateau ages, yielded by $\mathrm{M}$ and $\mathrm{O}$ - ca. $1500 \mathrm{My}$ and ca. 1600 My, respectively_are clearly distinguishable from the older and younger age groups.

Age group 3. Ages range from $1720-1890$ My (4 grains).-Three grains yielded plateau ages: $\mathrm{Z}=1723 \pm 6 \mathrm{My}, \mathrm{C}=1782 \pm 5 \mathrm{My}$ and $\mathrm{F}=1889 \pm 5$ My; and one gave a minimum age: $\mathrm{A}>1862 \pm 22$ My. Grains A and C have a stubby euhedral shape, while the other two are round with abraded surfaces, suggesting a detrital origin and absence of a younger mantle. Grain Z, which lacks an 
Fig. 7. Sample 6, age diagram for a quartzite of the Signehamna unit from the east coast of Krossfjorden. See caption with Fig. 3. Photographs show the well rounded shape of detrital zircon grains; the largest grain is ca. $0.7 \mathrm{~mm}$ across.

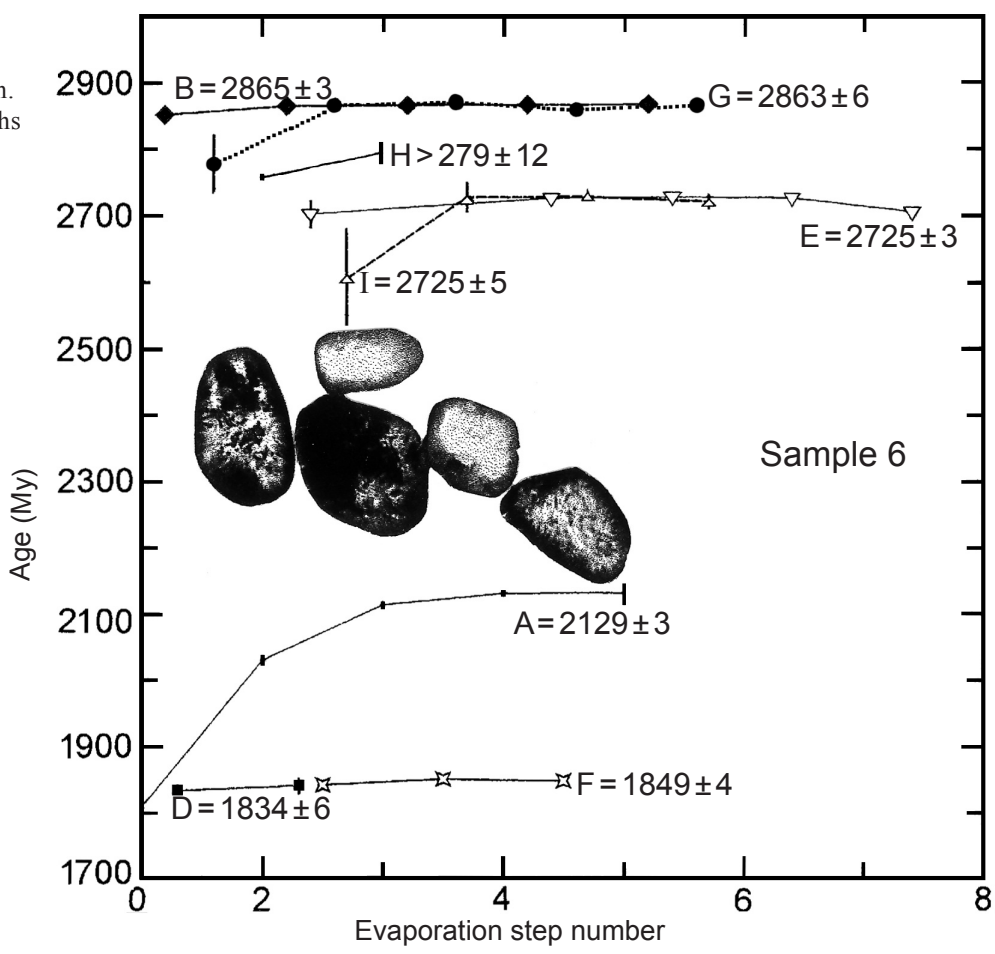

overgrowth, gave an age of ca. 1670 My during its early evaporation stages.

Age group 4. Ages older than 2700 My (3 grains).-Three short prismatic grains (Q, S and E) yielded Late Archaean ages of $2700 \pm 100 \mathrm{My}$, $>2792 \pm 19 \mathrm{My}$, and one step age of $>2922 \pm 13$ My, respectively. All grains of this age group are of detrital origin, and they may even have experienced more than one cycle of erosion and deposition.

Sample 5. Gneissose granite xenolith in the grey granite from Kollerbreen, north-east Krossfjorden.-A grey granite similar to sample 2 occurs at the exit of Kollerbreen (Fig. 1) and is intruded into the Signehamna schists to the west (Lange \& Hellebrandt 1999). A large number of angular xenoliths of schists, gneisses and granitic rocks are included in this grey granite.

A gneissose granite xenolith, having a smooth, but sharp contact with the host Caledonian grey granite, was sampled for dating. The gneissose granite xenoliths themselves contain xenolithic fragments of fine-grained, schistose metapelitic rocks. The schistosity within the schist xenoliths lies randomly in the host gneissose granite, illustrating that the protolith of the gneissose granite was intruded into the schists. The schistose xenoliths are similar to those of the adjacent Signehamna unit, though the degree of schistosity development is slightly weaker in the former. The primary contact between the gneissose granite and the Signehamna schists has been modified by later deformation.

The gneissose granite xenolith is a moderately potassic, calcalkaline, I-type granodiorite. The linear structure of the rock consists of biotite with or without hornblende, within a fine-grained granular quartz-feldspar matrix. No planar structure has been developed. Irregularly shaped K-feldspar, plagioclase (oligoclase) and quartz show weak, patchy extinction, locally forming small lensoid seams. Muscovite, sillimanite, and garnet are subordinate metamorphic minerals. This rock was originally a biotite granodiorite, with or without hornblende, and was converted into an orthogneiss. Later, fragments of this rock were incorporated into the younger Caledonian grey granite as xenoliths.

Biotite from the gneissose granite gave an ${ }^{40} \mathrm{Ar} /{ }^{39} \mathrm{Ar}$ incremental age of $419 \pm 1$ My (Fig. $2 b)$. The inverse isochron diagram defines a 


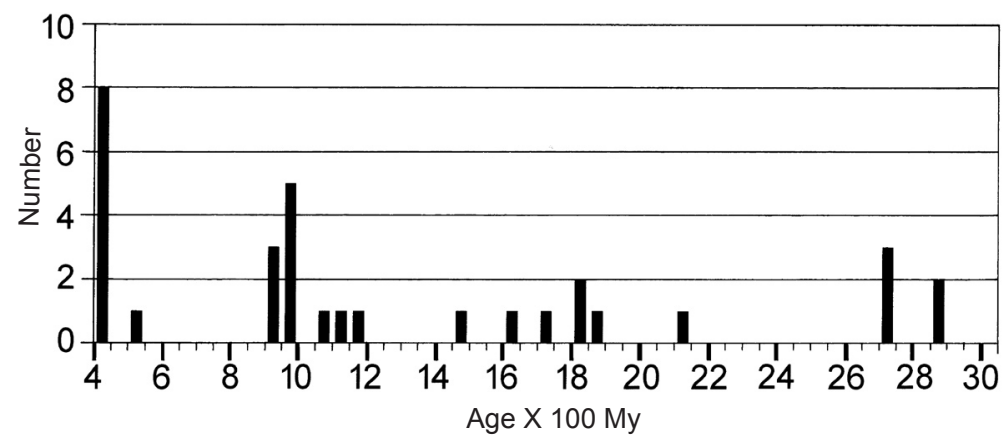

Fig. 8. Histogram of singlezircon $\mathrm{Pb}$-evaporation ages, plateau ages only, using all samples analysed in the present study. Samples are grouped in 50 My intervals.

regression line which corresponds to an age of $419 \pm 2$ My. These ages are similar to the Caledonian ages of the muscovite of sample 1 (mica schist) and zircon grains of samples 2 and 3 (grey granites).

The zircon grains from this rock (Fig. 6) are euhedral and subhedral in shape and have some inclusions. Weak zoning has been seen in some grains, suggesting a magmatic origin. A thin, CL-bright rim is parallel to the inner zoning and no CL-dark discordant rim has been seen.

The average age of four grains with plateau ages (B, C, D and F) is $955 \pm 4$ My. Grain E gave a slightly younger age of $940 \pm 3$ My (minimum or plateau uncertain), probably due to the more metamict structure of the grain. The obtained average age of ca. $955 \mathrm{My}$ is considered to be the primary crystallization age of the protolith granite of this orthogneiss.

Since the schistose rocks are xenoliths within this gneissose granite, their sedimentary protoliths must be older than ca. $955 \mathrm{My}$, i.e. Mesoproterozoic or older. They may be derived from the Signehamna schists, or some metasedimentary succession at greater depths.

All analysed zircon grains of this sample show ages younger than $955 \mathrm{My}$ at the beginning of analyses, and this suggests either a partial resetting of the zircons' U-Pb isotope systems, or younger mantle growth during Caledonian time.

Sample 6. Quartzite from the Signehamna unit, east of Krossfjorden.-Generalfjella marbles in the western limb of the regional synform on the mountain slopes along the eastern coast of Krossfjorden (Fig. 1) are thrust to the west (Lange \& Hellebrandt 1999) onto a thick sequence of phyllites and micaceous schists with interbedded quartzites, which are designated as the Signehamna unit. Brittle duplex structures some tens of metres thick show distinct westward vergence both below and above the thrust. The dated quartzite was collected ca. $20 \mathrm{~m}$ from the contact between the schists and marbles. Quartz in the rock is completely recrystallized into polygonal grains, forming small lensoidal aggregates surrounded by phyllosilicate flakes.

Zircon grains are well rounded with rough surfaces, evidently reflecting their detrital origin (Fig. 7). Eight dated grains were subdivided into three age groups.

Age group 1. Ages ca. 1850 My (2 grains).-Grain D, 1834 \pm 6 My (two step age), is lightly abraded, transparent, light pink in colour and is probably a fragment of a long prismatic grain, while grain F, $1849 \pm 4$ My (plateau age), is a strongly abraded, transparent, dark pink grain. The ${ }^{206} \mathrm{~Pb} / 208 \mathrm{~Pb}$ ratios of these two grains are somewhat different, suggesting derivation from different sources. These are the youngest detrital zircon ages so far obtained from this specific sample.

Age group 2. An age ca. 2130 My (1 grain).Grain A yielded plateau age of $2129 \pm 3$ My. This is a well rounded grain, probably due to strong abrasion.

Age group 3. Ages range from ca. 2790 - 2860 My (5 grains).-Two well rounded grains, E with a round and elongated form, and I, having an almost spherical shape, gave plateau ages of $2725 \pm 3$ My and $2725 \pm 5$ My, respectively. In spite of their different appearances, their ${ }^{206} \mathrm{~Pb} /$ ${ }^{208} \mathrm{~Pb}$ ratios are similar, suggesting probable derivation from the same source.

Three grains yielded still older ages: plateau ages of $\mathrm{G}=2863 \pm 6 \mathrm{My}$ and $\mathrm{B}=2865 \pm 3 \mathrm{My}$, and a minimum age of $\mathrm{H}>2791 \pm 12 \mathrm{My}$. The actual age of grain $\mathrm{H}$ may be considerably greater than 
the minimum age. The first two grains are somewhat less rounded than grain $\mathrm{H}$, and very similar ${ }^{206} \mathrm{~Pb} /{ }^{208} \mathrm{~Pb}$ ratios, suggesting a common source. Their less rounded character may mean that these grains had not experienced many cycles of redeposition.

The four grains of this age group, excluding grain $\mathrm{H}$, can be further divided into two subgroups, aged ca. $2725 \mathrm{My}$ and $2865 \mathrm{My}$. The relatively narrow age ranges of the age groups may indicate that the protolith of the sampled quartzite is a deposit (possibly fluvial) that collected detrital materials from relatively restricted areas. The single-zircon ages presented above show that the Signahamna quartzite is younger than ca. $1800 \mathrm{My}$.

Previous multi-grain ${ }^{207} \mathrm{~Pb} /{ }^{206} \mathrm{~Pb}$ single-step evaporation analysis of zircon populations from a garnet-biotite schist of the Signehamna unit, located ca. $6 \mathrm{~km}$ south and a few hundred metres below the quartzite sample, yielded mixed ages of detrital zircon grains of ca. $1645 \mathrm{My}$ and $1660 \mathrm{My}$ (Tebenkov, unpubl. data). These data indicate that the schists of the Signehamna unit are probably younger than 1650 My old.

\section{Summary and discussion}

The isotopic dating results presented here provide important constraints on the timing and extent of Caledonian and pre-Caledonian tectonothermal events in the north-west Spitsbergen migmatitemetasupracrustal complex and the pre-Caledonian source areas of the metasedimentary rocks (Fig. 8).

\section{Caledonian events}

The grey granites of samples 2 and 3 yielded Caledonian single-zircon magmatic ages of 419 to $427 \mathrm{My}$, consistent with the two ${ }^{40} \mathrm{Ar} /{ }^{39} \mathrm{Ar}$ ages of micas, 419 and $420 \mathrm{My}$, from strongly foliated schists. Granite bodies of this type occur more commonly in the northern parts of this area and along the boundaries between the north-south trending structural zones in the southern parts. These granites contain xenoliths of the metasupracrustals, orthogneisses and migmatites.

The older rocks, such as the gneissose granite (sample 5) and the migmatite neosome (sample 4) show ages of ca. 430-460 My in the early evaporation steps, indicating Caledonian growth of zircon rims, or partial resetting of the isotope system. These younger ages are consistent with the previous $\mathrm{K}-\mathrm{Ar}$ and $\mathrm{Rb}-\mathrm{Sr}$ results, representing Caledonian thermal events from various parts of this area (Gayer et al. 1966; Hjelle 1979; Krasil'ščikov 1979; Ravich 1979; Balašov et al. 1996a).

The ${ }^{40} \mathrm{Ar} /{ }^{39} \mathrm{Ar}$ age of $420 \mathrm{My}$ from sample 1 indicates that the reverse faults along the limbs of the regional synform of the Generalfjella marbles (Fig. 1) were active during Late Caledonian time.

No Early Caledonian ages (Ordovician) of ca. 470 My (Ohta et al. 1984; Ohta et al. 1989; Dallmeyer et al. 1990a) have yet been obtained from the rocks of this area. An Ordovician metamorphic climax with the formation of eclogite has been proposed by Gromet \& Gee (1998) in Biscayerhalvøya further to the northeast. This may means that an Early Caledonian subduction event did not influence the rocks of north-west Spitsbergen and this area was located at a different tectonic position from south-west Spitsbergen (Ohta et al. 1989).

\section{Early Cambrian event}

Two Early Paleozoic single-zircon minimum ages were obtained: 512 My (sample 2) and 522 My (sample 3).

There is a hiatus in the Middle Cambrian stratigraphy of Svalbard (e.g. Harland 1997), but no deformational event of this time has been recognized. On the other hand, hornblende ${ }^{40} \mathrm{Ar} /$ ${ }^{39} \mathrm{Ar}$ ages of 500 and $540 \mathrm{My}$ were reported from the gneisses from Biscayerhalvøya (Peucat et al. 1989; Dallmeyer et al. 1990b). High-P metamorphism in that area has been proposed to have occurred $>455$ Mya (sphene U-Pb age) by Gromet \& Gee (1998), which is near to these ages. However, there are not yet enough data to make generalizations about tectonothermal events of this period.

\section{Grenvillian events}

The "Grenvillian" interval embraces a time span from ca. 950 Mya to ca. 1270 Mya (Gower 1990). The population of zircon ages in this range is the largest in samples 4 and 5. The thermal event at ca. 950 Mya was probably the most pronounced in this area. This age is also represented in the inherited zircon grains of the grey granite 
samples 3 and the age subgroups $1 \mathrm{a}$ and $1 \mathrm{~b}$ of sample 4 of the migmatite neosome. Subsequent partial Pb-loss or Caledonian zircon overgrowth is inferred from the younger ages obtained at the beginning of evaporation. The overgrowths are usually thin and the cores are mostly rounded in shape, with well developed magmatic zoning.

There is evidence for Grenvillian granite activity in neighbouring areas to the east (Fig. 1). An U-Pb lower intercept age of ca. 950 My has been reported from a meta-granite on Biscayerhalvøya (Peucat et al. 1989) and similar ages, ca. $960 \mathrm{My}$, were obtained by the single-zircon $\mathrm{Pb}$-evaporation method by Ohta \& Larionov (1998) from a granite dyke cutting metasediments in Liefdefjorden.

The three-fold subdivision of the ages within the Grenvillian range (910-1150 My), seen in migmatite neosome (sample 4), could reflect different phases within a protracted Grenvillian event. Similarly, two distinct age groups, ca. 1100 and ca. $960 \mathrm{My}$, can be distinguished in the north-west Hornsund area, south-western Spitsbergen (Gavrilenko et al. 1993; Balašov et al. 1995; Balašov et al. 1996b). A distinctive granite-quartz porphyry complex in northern Nordaustlandet in north-east Svalbard also yielded Grenvillian ages. The eruptive complex, having angular unconformities both below and above (Ohta 1982; Gee \& Tebenkov 1996), is intruded by ca. 950 My old granitic rocks (Gee et al. 1995; Johansson \& Larionov 1996; Johansson et al. 2000).

It may be possible to distinguish an early magmatic phase 1000-1200 Mya and a later metamorphic phase with granitoid emplacement, ca. 930-950 Mya in Svalbard, both within the interval of the Grenvillian.

Interestingly, no Grenvillian ages have yet been detected in western Ny Friesland, making it the only Caledonian block in Svalbard without a record of Grenvillian event. Gee \& Page (1994) have therefore postulated that western Ny Friesland represents an independent terrane, brought into present position after the Grenvillian period.

\section{The timing of regional migmatization}

The rounded shape of zircon grains could be the result of either abrasion during erosion and sedimentation or metamorphic resorption, and these alternative interpretations lead to different conclusions for the timing of the main migmatization in this area. Criteria for discriminating these alternatives are ambiguous (e.g. Brouand et al. 1990; Cornell et al. 1998; Hartmann et al. 2000; Williams 2001). If the rounded cores were formed by sedimentary processes, then the sedimentary protoliths of the schists, gneisses and migmatites were of postGrenvillian origin. In this scenario, the main migmatization event occurred in Caledonian time. The second possibility is that the cores were rounded by resorption of Grenvillian zircon grains during Caledonian thermal events, and that migmatization occurred during the Grenvillian period. The sedimentary protoliths, in this case, could be Mesoproterozoic or older. This second interpretation is preferred for this area, since no clear Caledonian step-ages were found in samples 4 and 5, except for the early steps of evaporation with relatively large errors. At the present stage of study there are therefore two possible interpretations of the timing of main migmatization: either Grenvillian or Caledonian.

\section{Provenance of the metasupracrustal rocks}

The quartzite of the Signehamna unit (sample 6) was subjected to upper greenschist facies metamorphism and its zircons show no sign of Caledonian growth. This sample contains no detrital zircon grains with Grenvillian ages, the youngest age obtained being ca. $1830 \mathrm{My}$. The results indicate that this quartzite was deposited after 1830 My probably during Mesoproterozoic time before the Grenvillian, and escaped metamorphism of high enough grade to cause new zircon growth during both the Grenvillian and Caledonian periods.

Most authors of previous works (e.g. Gee \& Hjelle 1966; Hjelle 1979; Krasil'ščikov 1979) considered that the schist and gneiss paleosomes of the migmatites were derived from the supracrustal successions. The youngest plateau ages from the round zircon grains in the migmatite neosome (sample 4) are ca. 1051 My (grain N) and 1153 My (grain Y). Thus, if these grains really are detrital, the age of the sedimentation must be younger than ca. 1050 My, but older than the protolith of the gneissose granite (sample 5), with an age of $955 \mathrm{My}$, the latter contain schistose rock xenoliths resembling the Signehamna schists. 
Two zircon grains of age group 2 of the migmatite neosome (sample 4), yielding plateau ages of ca. 1500 My to $1600 \mathrm{My}$, are short prismatic, subhedral grains without apparent traces of the Caledonian overgrowth. They may form two subgroups, ca.1500 My and ca. 1600 My old.

Similar age groups have been revealed by dating of zircon from rocks elsewhere in northern Svalbard:

1) Xenocrystic zircon grains in a felsic tuffite interbedded with Devonian sandstones in middlewestern Biscayerhalvøya (Hellman et al. 1998) fall in the age range of $1350-1600 \mathrm{My}$.

2) One population of detrital zircon grains from the Polhem Formation of northern Ny Friesland (Hellman et al. 1997) gave ages of 1450 - 1500 My.

3) Several detrital zircon grains from metapsammites of the Smutsbreen Formation in southwestern Ny Friesland (Gee \& Hellman 1996) yielded ages of 1200-1600 My.

4) A granitic clast from the Vendian tillite of middle Nordaustlandet (Larionov et al. 1998) was dated at ca. $1500 \mathrm{My}$.

These data indicate one or more phases of thermal activity in the sedimentary source areas during the middle Mesoproterozoic, though age groups of 2) and 3) are in western Ny Friesland and were, according to Gee \& Page (1994), located away from other areas during Grenvillian period.

\section{Paleoproterozoic events}

Zircon grains yielding ages of 1700-1900 My have been found in the migmatite neosome (sample 4) and Signehamna quartzite (sample 6), defining a distinct age group. More than half of these grains show rough surfaces, indicating their detrital origin from various sources. Three age subgroups, ca. $1720 \mathrm{My}$, ca. $1800 \mathrm{My}$ and 1850 - $1890 \mathrm{My}$, can be recognized in these results, and these may represent different tectonothermal phases during a long-lived latest Paleoproterozoic event.

Granites containing zircon grains with ages of ca. 1750 My are widespread in the western half of Ny Friesland (e.g. Gee et al. 1992; Johansson et al. 1995; Johansson \& Larionov 1996). This area is the nearest candidate of source area for the detrital zircon grains of the present area.
One middle Paleoproterozoic detrital zircon age, ca. $2130 \mathrm{My}$, has been detected from the quartzite of the Signehamna unit (sample 6).

\section{Archean ages}

A total of 8 grains, 3 from the migmatite neosome (sample 4) and 5 from the Signehamna quartzite (sample 6), have yielded Late Archean ages of ca. 2700 My and older. All these ages correspond to the crystallization time of detrital cores and imply that these grains may have experienced more than one depositional cycle.

As a whole, single-zircon $\mathrm{Pb}$-evaporation dating results indicate an extensive Grenvillian high-temperature event in north-west Spitsbergen, while evidence for the Caledonian event is restricted to the intrusive granites and low temperature recrystallization. Provenances of the metasupracrustal rocks can be expected in palinspastically neighbouring continental plates.

Acknowledgements.-Fieldwork and sample collection were conducted as part of the Norwegian Polar Institute's geological mapping project. The ${ }^{40} \mathrm{Ar} /{ }^{39} \mathrm{Ar}$ analyses were performed at the Centre d'Etudes Nucleaires, Grenoble, France, and all zircon isotopic analyses have been carried out at the Laboratory for Isotope Geology at the Swedish Museum of Natural History, Stockholm. Many constructive comments and language improvements by Prof. M. Bjørnerud are deeply appreciated.

\section{References}

Abakumov, S. A. 1979: Peculiar features of regional metamorphism of northwestern Spitsbergen. The geological development of Svalbard during the Precambrian, Lower Palaeozoic, and Devonian. Nor. Polarinst. Skr. 167, 29-36.

Balašov, Ju. A., Tebenkov, A. M., Ohta, Y., Larionov, A. N., Sirotkin, A. N., Gannibal, L. F. \& Ruyngenen, G. I. 1995: Grenvillian $\mathrm{U}-\mathrm{Pb}$ zircon ages of quartz porphyry and rhyolite clasts in a metaconglomerate at Vimsodden, southwestern Spitsbergen. Polar Res. 14, 291-302.

Balašov, Ju. A., Peucat, J. J., Tebenkov, A. M., Ohta, Y. \& Sirotkin, A. N. 1996a: Additional Rb-Sr and single-zircon datings of Caledonian granitoid rocks from Albert I Land, northwest Spitsbergen. Polar Res. 15, 153-165.

Balašov, Ju. A., Peucat, J. J., Tebenkov, A. M., Ohta, Y., Larionov, A. N., Sirotkin, A. N. \& Bjørnerud, M. 1996b: $\mathrm{Rb}-\mathrm{Sr}$ whole rock and $\mathrm{U}-\mathrm{Pb}$ zircon datings of the graniticgabbroic rocks from the Skålfjellet Subgroup, southwest Spitsbergen. Polar Res. 15, 167-181.

Brouand, M., Banzet, G. \& Barbey, P. 1990: Zircon behaviour during crustal anatexis. Evidence from the Tibetan Slab migmatites (Nepal). J. Volcan. Geotherm. Res. 44, 143- 
161.

Bucher-Nurminen, K. 1981: Petrology of chlorite-spinel marbles from NW Spitsbergen (Svalbard). Lithos 14, $203-$ 213.

Cornell, D., Åberg, A., Schersten, A. \& Armstrong, R. 1998: The CANUTE model for Ion-probe U-Pb zircon dating and its application to the Borås mafic intrusion. 23rd Nordic Geological Winter Meeting, Århus, 1998. Abstract volume, p. 53 .

Dallmeyer, R. D., Peucat, J. J., Hirajima, T. \& Ohta, Y. 1990a: Tectothermal chronology within a blueschist-eclogite complex, west-central Spitsbergen, Svalbard: evidence from ${ }^{40} \mathrm{Ar} /{ }^{39} \mathrm{Ar}$ and $\mathrm{Rb}-\mathrm{Sr}$ mineral ages. Lithos $24,291-$ 304.

Dallmeyer, R. D., Peucat, J. J. \& Ohta, Y. 1990b: Tectonothermal evolution of contrasting metamorphic complexes in northwest Spitsbergen (Biskayerhalvøya): evidence from ${ }^{40} \mathrm{Ar} /{ }^{39} \mathrm{Ar}$ and $\mathrm{Rb}-\mathrm{Sr}$ mineral ages. Geol. Soc. Am. Bull. 102, 653-663.

Dalziel, I. W. D. 1997: Neoproterozoic-Paleozoic geography and tectonics: review, hypothesis, environmental speculation. Geol. Soc. Am. Bull. 109, 16-42.

Gavrilenko, B. V., Balašov, Ju. A., Tebenkov, A. M. \& Larionov, A. N. 1993: U-Pb ranneproterozojskij vozrast "reliktovogo" cirkona iz vysokokalievych kvarcevych porfirov Zemli Vedel-Jarlsberga JuZ Spicbergena. (U$\mathrm{Pb}$ early Proterozoic age of "relict" zircon from high potassium quartz porphyries of Wedel Jarlsberg Land, south-west Spitsbergen.) Geochimija 1, 154-158.

Gayer, R. A., Gee, D. G., Harland, W. B., Miller, J. A., Spall, H. R., Wallis, R. H. \& Winsnes, T. S. 1966: Radiometric age determinations on rocks from Spitsbergen. Nor. Polarinst. Skr. 137.

Gee, D. G. \& Hellman, F. J. 1996: Zircon Pb evaporation ages from the Smutsbreen Formation, southern Ny Friesland: new evidence for Caledonian thrusting in Svalbard's Eastern Terrane. Zeitsch. Geol. Wiss. 24, 429-439.

Gee, D. G. \& Hjelle, A. 1966: On the crystalline rocks of north-west Spitsbergen. Nor. Polarinst. Arb. 1964. Olso: Norwegian Polar Institute.

Gee, D. G., Johansson, Å., Ohta, Y., Tebenkov, A. M., Krasil’ščikov, A. A., Barasov, Yu. A., Larionov, A. N., Gannibal, L. S. \& Ryungenen, G. I. 1995: Grenvillian basement and a major unconformity within the Caledonides of Nordaustlandet, Svalbard. Precambrian Res. 70, 215-234.

Gee, D. G. \& Page, L. M. 1994: Caledonian terrane assembly on Svalbard; new evidence from ${ }^{40} \mathrm{Ar} /{ }^{39} \mathrm{Ar}$ dating in $\mathrm{Ny}$ Friesland. Am. J. Sci. 294, 1166-1186.

Gee, D. G., Schouenborg, B., Peucat, J., Abakumov, S. A., Krasil'ščikov, A. A. \& Tebenkov, A. M. 1992: New evidence of basement in the Svalbard Caledonides: early Proterozoic zircon ages from Ny Friesland granites. Nor. Geol. Tidskr. 72, 181-190.

Gee, D. G. \& Tebenkov, A. M. 1996: Two major unconformities beneath the Neoproterozoic Murchisonfjorden Supergroup in the Caledonides of central Nordaustlandet, Svalbard. Polar Res. 15, 81-91.

Gower, C. F. 1990: Mid-Proterozoic evolution of the eastern Grenville province, Canada. Geol. Fören. Stockholm Förh. 112, 127-139.

Gromet, L. P. \& Gee, D. G. 1998: An evaluation of the age of high-grade metamorphism in the Caledonian of Biskayerhalvøya, NW Spitsbergen. Geol. Fören. Stockholm Förh. 120, 199-208.
Harland, W. B. 1997: The Geology of Svalbard. Geological Society Memoir 17. London.

Hartmann, L. A., Deite, J. A. D., da Silva, L. C., Remus, M. V. D., McNaughton, N. J., Groves, D. I., Fletcher, I. R., Santos, J. O. S. \& Vasconcellos, M. A. Z. 2000: Advances in SHRIMP geochronology and their impact on understanding the tectonic and metallogenic evolution of South Brasil. Aust. J. Earth Sci. 47, 829-844.

Hellman, F. J., Gee, D. G., Johansson, Å. \& Witt-Nilsson, P. 1997: Single-grain zircon $\mathrm{Pb}$-evaporation geochronology constrains basement-cover relationships in the Lower Hecla Hoek Complex of northern Ny Friesland, Svalbard. Chem. Geol. 137, 117-134.

Hellman, F. J., Gee, D. G., Gjelsvik, T. \& Tebenkov, A. M. 1998: Provenance and tectonic implications of Paleoproterozoic (c. $1740 \mathrm{Ma}$ ) quartz porphyry clasts in the basal Old Red Sandstone (Lilljeborgfjellet Conglomerate Formation) of northwestern Svalbard's Caledonides. Geol. Mag. 135, 755-768.

Hjelle, A. 1979: Aspects of the geology of northwest Spitsbergen. The geological development of Svalbard during the Precambrian, Lower Palaeozoic, and Devonian. Nor. Polarinst. Skr. 167, 37-62.

Hjelle, A. \& Lauritzen, Ø. 1982: Geological map Svalbard 1:500,000, Sheet $3 G$ Spitsbergen northern part. Nor. Polarinst. Skr. 154-C.

Hjelle, A. \& Ohta Y. 1974: Contribution to the geology of north western Spitsbergen. Nor. Polarinst. Skr. 158.

Holtedahl, O. 1914: New features in the geology of northwestern Spitsbergen. Am. J. Sci. ser. 4, 37, 415-424.

Holtedahl, O. 1926: Notes on the geology of northwestern Spitsbergen. Skr. 8. Oslo: Norges Svalbard- og Ishavsundersøkelser (Norwegian Polar Institute).

Johansson, Å., Gee, D. G., Björklund, L. \& Witt-Nilsson, P. 1995: Isotope studies of granitoids from the Bangenhuk formation, Ny Friesland orogeny, Svalbard. Geol. Mag. 132, 303-320.

Johansson, A. \& Larionov, A. N. 1996: U-Pb ages from the Eastern Terrane of the Svalbard Caledonides: evidence for Palaeoproterozoic, Grenvillian and Caledonian tectonism. Geol. Fören. Stockholm Förh. 118 A, 38-39.

Johansson, Å., Larionov, A. N., Tebenkov, A. M., Gee, D. G., Whitehouse, M. J. \& Vestin, J. 2000: Grenvillian magmatism of western and central Nordaustlandet, northeastern Svalbard. Trans. R. Soc. Edinb. Earth Sci. 90, 221-254.

Klaper, E. M. 1986: The metamorphic evolution of garnetcordierite-sillimanite gneisses of NW Spitsbergen (Svalbard). Schweiz. Miner. Petrogr. Mitt. 66, 295-313.

Kober, B. 1986: Whole-grain evaporation for ${ }^{207} \mathrm{~Pb} /{ }^{206} \mathrm{~Pb}$-ageinvestigations on single zircons using a double-filament thermal ion source. Contrib. Miner. Petrol. 93, 482-490.

Kober, B. 1987: Single-zircon evaporation combined with $\mathrm{Pb}^{+}$ emitter bedding for ${ }^{207} \mathrm{~Pb} /{ }^{206} \mathrm{~Pb}$-age investigations using thermal ion mass-spectrometery, and implications to zirconology. Contrib. Miner. Petrol. 96, 63-71.

Krasil'ščikov, A. A. 1979: Stratigraphy and tectonics of the Precambrian of Svalbard. The geological development of Svalbard during the Precambrian, Lower Palaeozoic, and Devonian. Nor. Polarinst. Skr. 167, 73-79.

Lange, M. \& Hellebrandt, B. 1999: Metamorphic conditions of the metasedimentary rocks of the crystalline basement in the southwestern Haakon VII Land, Northwest-Spitsbergen, Svalbard, using microprobe analysis on garnets. Münst. Forsch. Geol. Paläontol. 86, 1-10. 
Larionov, A. N., Tebenkov, A. M. \& Gee, D. G. 1998: Pb-Pb single-zircon ages of granitoid boulders from the Vendian tillite of Wahlenbergfjorden, Nordaustlandet, Svalbard. Polar Res. 17, 71-80.

Ludwig, K. R. 1991: ISOPLOT-a plotting and regression program for radiogenic-isotope data, version 2.56. U.S. Geol. Surv. Open File Rep. 91-445.

Maluski, H., Coulon, C., Popoff, M. \& Baudin, P. 1995: ${ }^{40} \mathrm{Ar} /$ ${ }^{39} \mathrm{Ar}$ chronology, petrology and geodynamic setting of Mesozoic to Early Cenozoic magmatism from the Benue Trough, Nigeria. J. Geol. Soc. Lond. 157, 311-326.

Maniar, P. D. \& Piccoli, P. M. 1989: Tectonic discrimination of granitoids. Geol. Soc. Am. Bull. 101, 635-643.

Ohta, Y. 1969: The geology and structure of metamorphic rocks in the Smeerenburgfjorden area, north-west Vestspitsbergen. Nor. Polarinst. Arb. 1967, 52-72.

Ohta, Y. 1982: Hecla Hoek rocks in central and western Nordaustlandet. Nor. Polarinst. Skr. 178.

Ohta, Y., Dallmeyer, R. D. \& Peucat, J. J. 1989: Caledonian terranes in Svalbard. Geol. Soc. Am. Spec. Pap. 230, 1-15.

Ohta, Y., Hiroi, Y. \& Hirajima, T. 1984: Additional evidence of pre-Silurian high-pressure metamorphic rocks in Spitsbergen. Polar Res. new ser. 1, 215-218.

Ohta, Y. \& Larionov, A. N. 1998: Grenvillian single-grain zircon $\mathrm{Pb}$ age of a granitic rock from the southern island of Hesteskoholmen, Liefdefjorden, NW Spitsbergen. Polar Res. 17, 147-154.

Ohta, Y., Larionov, A. N., Tebenkov, A. M., Lepvrier, C., Maluski, H., Lange, M. \& Hellebrandt, B. in press: Single-zircon Pb-evaporation on $40 \mathrm{Ar} / 39 \mathrm{Ar}$ dating of the metamorphic and granitic rocks in north-west Spitsbergen: data tables. Nor. Polarinst. Intern. Rapp.ser. 9. Tromsø: Norwegian Polar Institute.

Peletz, G., Greving, S. \& Thiedig, F. 1997: Der tektonische Bau des Ueberschiebungsguertels auf der Mitrahalvøya,
Albert I Land, NW-Spitzbergen. Münst. Forsch. Geol. Paläontol. 82, 79-86.

Peucat, J. J., Ohta, Y., Gee, D. G., \& Bernard-Griffiths, J. 1989: U-Pb, Sr and Nd evidence for Grenvillian and latest Proterozoic tectonothermal activity in the Spitsbergen Caledonides, Arctic Ocean. Lithos 22, 275-285.

Piepjohn, K., Greving, S., Peletz, G., Thielemann, T., Werner, S. \& Thiedig, F. 1997: Kaledonische und svalbardische Entwicklung im kristallinen Basement auf der Mitrahalvøya, Albert I Land, NW Spitzbergen. Münst. Forsch. Geol. Paläontol. 82, 53-72.

Ravich, M. G. 1979: Is there an early Precambrian granitegneiss complex in north-western Spitsbergen? The geological development of Svalbard during the Precambrian, Lower Palaeozoic, and Devonian. Nor. Polarinst. Skr. 167, 9-28.

Sirotkin, A. N. 1996: Regional'nyj metamorfizm ranneproterozoijskich-rannepaleozojskich kompleksov Špicbergena. (Regional metamorphism of Early ProterozoicEarly Paleozoic complex of Spitsbergen.) In: Geologogeofizičeskie charakteristiki litosfery Arktičeskogo regiona. (Geological-geophysical characteristics of the lithosphere of the Arctic region.) Pp. 241-254. Saint Petersburg: VNIIOkeangeologija.

Stacey, J. S. \& Kramers, J. D. 1975: Approximation of Terrestrial lead isotope evolution by a two-stage model. Earth Planet. Sci. Lett. 26, 207-221.

Torsvik, T. H. \& Rehnström, E. F. 2000: Cambrian Paleomagnetic data from Baltic: implication for true polar wandering and Cambrian paleogeography. J. Geol. Soc. Lond. $158,321-329$.

Williams, I. S. 2001: Response of detrital zircon and monazite, and their $\mathrm{U}-\mathrm{Pb}$ isotopic systems, to regional metamorphism and host-rock partial melting, Cooma Complex, Southeastern Australia. Aust. J. Earth Sci. 48, 557-580. 
